Provided for non-commercial research and education use. Not for reproduction, distribution or commercial use.

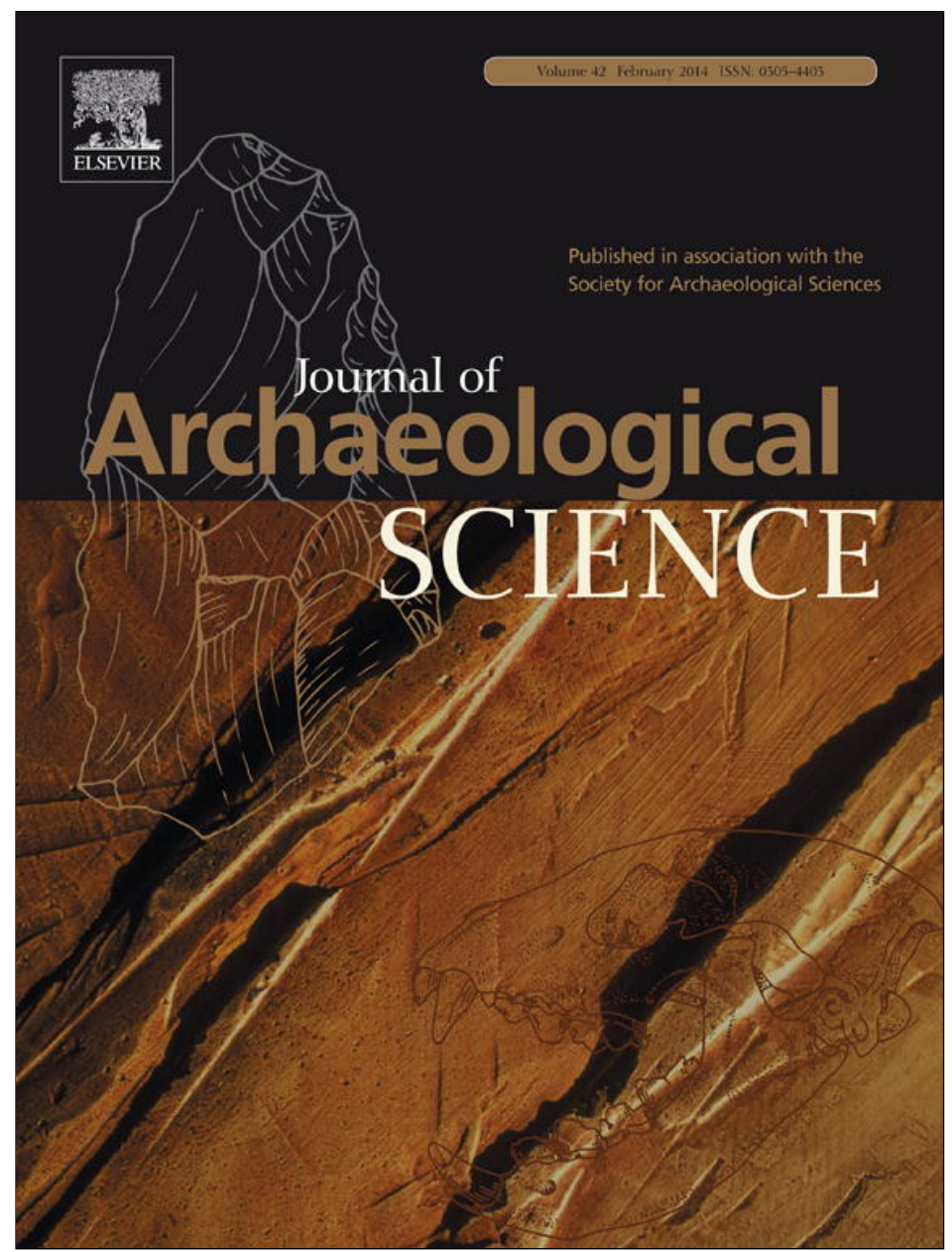

This article appeared in a journal published by Elsevier. The attached copy is furnished to the author for internal non-commercial research and education use, including for instruction at the authors institution and sharing with colleagues.

Other uses, including reproduction and distribution, or selling or licensing copies, or posting to personal, institutional or third party websites are prohibited.

In most cases authors are permitted to post their version of the article (e.g. in Word or Tex form) to their personal website or institutional repository. Authors requiring further information regarding Elsevier's archiving and manuscript policies are encouraged to visit:

http://www.elsevier.com/authorsrights 
Review

\title{
Cryptotephra as a dating and correlation tool in archaeology
}

\author{
C.S. Lane ${ }^{\mathrm{a}, *}$, V.L. Cullen ${ }^{\mathrm{a}}$, D. White ${ }^{\mathrm{b}}$, C.W.F. Bramham-Law ${ }^{\mathrm{a}}$, V.C. Smith ${ }^{\mathrm{a}}$ \\ ${ }^{a}$ Research Laboratory for Archaeology and the History of Art, University of Oxford, Dyson Perrins, South Parks Road, Oxford, UK \\ ${ }^{\mathrm{b}}$ Archaeology, University of Southampton, Avenue Campus, Highfield, Southampton SO17 1BF, UK
}

\section{A R T I C L E I N F O}

\section{Article history:}

Received 12 August 2013

Received in revised form

21 October 2013

Accepted 25 October 2013

\section{Keywords:}

Volcanic ash

Cryptotephra

Archaeology

Chronology

Tephrostratigraphy

\begin{abstract}
A B S T R A C T
A new development in archaeological chronology involves the use of far travelled volcanic ash which may form discrete but invisible layers within a site's stratigraphy. Known as cryptotephra, these horizons can provide isochrons for the precise correlation of archaeological records at single moments in time, removing, or at least significantly reducing, temporal uncertainty within inter-site comparisons. When a tephra can be dated elsewhere, its age can be imported between records, providing an independent check on other dating methods in use and valuable age estimates for difficult to date sequences. The use of cryptotephra layers to date and correlate palaeoenvironmental archives is well established and there exists a wealth of tephra compositional data and regional tephrostratigraphic frameworks from which archaeological cryptotephra studies can benefit greatly. Existing approaches to finding and analysing cryptotephra are easily adapted to archaeological sequences, so long as the often complex nature of archaeological stratigraphies and sediment taphonomy are borne in mind.
\end{abstract}

(C) 2013 Elsevier Ltd. All rights reserved.

\section{Introduction}

Explosive volcanic events typically generate large volumes of ash (tephra) that can be rapidly transported within the atmosphere and subsequently deposited onto the underlying landscape. Tephra deposits preserved within sedimentary sequences create time synchronous marker horizons (isochrons) that allow precise dating ("tephrochronology") and correlation of palaeoenvironmental or archaeological sites ("tephrostratigraphy") across wide geographical areas (e.g. Dugmore, 1989a; Lowe et al., 2012; Mangerud et al., 1984; Pyle et al., 2006; Turney, 1998). Visible tephra layers (typically $10 \mathrm{~s} \mathrm{~km}$ from the vent) are found preserved in a variety of depositional settings of varying ages throughout the world, and are used to date both important sedimentological sequences and palaeoclimate records (e.g. Abbott and Davies, 2012; Wulf et al., 2004) and archaeological sites (e.g. WoldeGabriel et al., 2005). In recent years palaeoenvironmental studies have demonstrated the potential of 'extending' the use of visible tephra isochrons by looking for non-visible tephra layers, known as cryptotephra, which can in some cases be found more than $1000(\mathrm{~s}) \mathrm{km}$ from their source (e.g. Blockley et al., 2007). Tephra layers may be "cryptic" due to a combination of their grain size (frequently below $125 \mu \mathrm{m}$ ), glass shard concentration and dilution within the host sediment. Whilst some cryptotephra layers may still have concentrations of

\footnotetext{
* Corresponding author. Tel.: +44 1865 285203; fax: +44 1865285220

E-mail address: Christine.lane@rlaha.ox.ac.uk (C.S. Lane).
}

several 1000s of glass shards per gram of dry sediment (s/g), others may have fewer than $10 \mathrm{~s} / \mathrm{g}$ and require a painstaking extraction from the host sediment (Section 3.4).

The advent of cryptotephra research has brought about improvements in the precision and accuracy of many site-specific age models (e.g., Finsinger et al., 2011), as well as advances in our ability to compare independently dated records, allowing evaluation of the synchronicity of abrupt environmental transitions across continental distances (Blockley et al., 2012; Lane et al., 2011a, 2013). Regional tephra frameworks are now being constructed (e.g. Davies et al., 2002, 2012), bolstered by the increasing number of palaeoenvironmental records found to contain multiple cryptotephra layers (e.g. Abbott and Davies, 2012; Wulf et al., 2012), which allow sites previously unconnected to be directly compared around and between these event horizons.

The use of far travelled tephra as suitable marker horizons in archaeological sites was first promoted over 2 decades ago at an UK Archaeological Science meeting (Dugmore, 1989a). Despite this, the adoption of cryptotephrochronology as a tool within archaeological research has been incremental. Some of the earliest and most successful applications have been within wetland sites (e.g. Dugmore, 1989b; Housley et al., 2010), where studies of land use go hand in hand with palaeoenvironmental investigations. More recently, novel cryptotephra investigations in archaeological sequences have successfully demonstrated the potential of looking for these non-visible, volcanic ash layers within archaeological cave and rock shelter sites as well as in palaeoenvironmental archives (Balascio et al., 2011; Blockley et al., 2006; Douka et al., 
2013; Lane et al., 2011b; Lowe et al., 2012; Plunkett et al., 2009). Consequently, the technique is now being promoted to a wider, archaeological audience, most specifically at recent conference sessions (e.g. the XVIII INQUA Bern 2011 session "Enhancing Tephrochronology and its Application in Archaeology and Palaeoenvironmental-change Studies", and in Helsinki at the 2012 European Archaeological Association session "Tephra and Archaeology - Chronological, Ecological and Cultural Dimensions"), but also by the publication of successful archaeological applications, as listed in Table 1 and Fig. 1.

This paper aims to review the gradual adoption of cryptotephrochronology as a stratigraphic and chronological tool within archaeological research, and considers the wider advantages of connecting archaeological sites to the palaeoenvironmental record. We provide some examples from the literature of both successful and complex case studies within a range of sedimentary contexts, which highlight the potential and limitations of the technique. In the second part of this paper, we discuss methodological considerations particular to archaeological cryptotephra investigations.

\section{Cryptotephra in archaeology}

Cryptotephra layers have been widely used as chronological markers, often alongside radiocarbon dating, within palaeoenvironmental studies of peatlands (e.g. Dugmore, 1989b; Wastegard, 2002) and lakes (e.g. Chambers et al., 2004; Lane et al., 2011a). In such records the rapidly accumulating sediments are ideal for preserving multiple cryptotephra layers, often with only minimal disturbance of the horizon (Davies et al., 2007; Dugmore et al., 1992; Payne et al., 2005). Consequently, cryptotephrochronology has been applied in a number of wetland archaeological sites, most notably in Ireland (Newman et al., 2007; Plunkett et al., 2009), Scotland (Housley et al., 2010) and Scandinavia (Balascio et al., 2011), which have received many tephra deposits from (mostly) Icelandic volcanoes during the Holocene and Lateglacial (Lawson et al., 2012; Swindles et al., 2011). The chronology of land use and vegetation change in Ireland during the Iron Age and Bronze Age, for example, is now well constrained by studies combining cryptotephra and radiocarbon dating (Newman et al., 2007; Plunkett et al., 2008). Key cryptotephra layers used to date and correlate peatlands and associated archaeological sites across much of Ireland include the Hekla 1 (AD 1104), AD 860 and the Microlite Tephra (755-680 BC; Plunkett et al., 2004, 2009). These eruptions have widely been attributed to Icelandic volcanic sources (Lawson et al., 2012; Plunkett et al., 2004), however recent work by Jensen et al. (2012) indicates that one fraction of the AD 860 eruption correlates to the Alaskan White River Ash (eastern lobe), offering trans-Atlantic correlations of palaeoenvironmental and archaeological archives.

Cryptotephrochronology has no temporal limit, providing that a tephra layer can be dated either directly by radiometric methods $\left({ }^{14} \mathrm{C}\right.$ or ${ }^{40} \mathrm{Ar} /{ }^{39} \mathrm{Ar}$; e.g. Smith et al., 2011; Morgan et al., 2012), or indirectly by dating associated materials with other methods (e.g.

Table 1

Summary of published cryptotephra investigations in archaeological records $(*=$ undated eruption).

\begin{tabular}{|c|c|c|c|c|c|c|c|}
\hline Site & Country & Site Type & Time period & $\begin{array}{l}\text { No. of } \\
\text { tephra } \\
\text { layers }\end{array}$ & Tephra layers identified (+age) & Volcanic centre & $\begin{array}{l}\text { Site (and tephra) } \\
\text { References }\end{array}$ \\
\hline $\begin{array}{l}\text { Fenton } \\
\text { Cottage }\end{array}$ & UK & Peat bog & Bronze Age - Iron Age & 1 & Hekla 4 & Hekla, Iceland & Wells et al., 1997 \\
\hline Raffin Fort & UK & Peat bog & Late Iron Age & 5 & $\begin{array}{l}\text { Hekla } 1 \text { (A.D. 1104) } \\
\text { A. D. } 860 \text { B/White River Ash (eastern lobe) }\end{array}$ & $\begin{array}{l}\text { Hekla, Iceland } \\
\text { Mount Bona- } \\
\text { Churchill, } \\
\text { Alaska }\end{array}$ & $\begin{array}{l}\text { Newman et al., 2007 } \\
\text { (Jensen et al., 2012) }\end{array}$ \\
\hline Ballynahatty & Ireland & Peat bog & Mesolithic - Neolithic & 4 & Unknown (Iceland?) & & Plunkett et al., 2008 \\
\hline Oldcroghan & Ireland & Peat bog & Middle - Late Bronze Age & 1 & Microlite Tephra (27052 - 629 BP) & $\begin{array}{l}\text { Unknown } \\
\text { (Iceland?) }\end{array}$ & Plunkett et al., 2009 \\
\hline Borgpollen & Norway & Shoreline & Iron Age & 4 & $\begin{array}{l}\text { Hekla AD1300 } \\
\text { Hekla AD } 1158 \\
\text { Hekla } 1 \text { (A.D. } 1104 \text { ) } \\
\text { A.D. } 860 \text { B/White River Ash (eastern lobe) }\end{array}$ & $\begin{array}{l}\text { Hekla, Iceland } \\
\text { Hekla, Iceland } \\
\text { Hekla, Iceland } \\
\text { Mount Bona- } \\
\text { Churchill, } \\
\text { Alaska }\end{array}$ & $\begin{array}{l}\text { Balascio et al., 2011 } \\
\text { (Jensen et al., 2012) }\end{array}$ \\
\hline Grabow & Germany & Floodplain & Lateglacial - Early Holocene & 1 & Unknown (Askja, Iceland?) & & Tolksdorf et al., 2013 \\
\hline Ahrenshöft & Germany & Open air & Lateglacial - Early Holocene & 1 & Unknown (Katla, Iceland?) & & Housley et al., 2012 \\
\hline $\begin{array}{l}\text { Golema } \\
\text { Pesht }\end{array}$ & Macedonia & Cave & Middle to Upper Palaeolithic & 1 & Campanian Ignimbrite (39135 - 39225 BP) & Campi Flegrei, Italy & Lowe et al., 2012 \\
\hline Klissoura & Greece & $\begin{array}{l}\text { Rock } \\
\text { shelter }\end{array}$ & Middle to Upper Palaeolithic & $2+$ & Campanian Ignimbrite (39135 - 39225 BP) & Campi Flegrei, Italy & Lowe et al., 2012 \\
\hline Franchthi & Greece & Cave & Middle to Upper Palaeolithic & 1 & Campanian Ignimbrite (39135 - 39225 BP) & Campi Flegrei, Italy & Lowe et al., 2012 \\
\hline Kozarnika & Bulgaria & Cave & Middle to Upper Palaeolithic & 2 & Campanian Ignimbrite (39135 - 39225 BP) & Campi Flegrei, Italy & Lowe et al., 2012 \\
\hline $\begin{array}{l}\text { Tabula } \\
\text { Traiana }\end{array}$ & Serbia & Cave & Middle to Upper Palaeolithic & 2 & Campanian Ignimbrite (39135 - 39225 BP) & Campi Flegrei, Italy & Boric et al., 2012 \\
\hline Theopetra & Greece & Cave & Middle to Upper Palaeolithic & 3 & $\begin{array}{l}\text { Green Tuff/Y6 } \\
\text { Upper Pumice* } \\
\text { Unit P }(121400-136200 \mathrm{BP})\end{array}$ & $\begin{array}{l}\text { Pantelleria, Italy } \\
\text { Nisyros Island, } \\
\text { Greece } \\
\text { Pantelleria, Italy }\end{array}$ & $\begin{array}{l}\text { Karkanas et al., in } \\
\text { press; (Tamburrino } \\
\text { et al., 2012) }\end{array}$ \\
\hline $\begin{array}{l}\text { Mezmaiskaya } \\
\text { Cave }\end{array}$ & Russia & Cave & Middle to Upper Palaeolithic & 2 & Unknown (Caucasus?) & & Golovanova et al., 2010 \\
\hline Haua Fteah & Libya & $\begin{array}{l}\text { Rock } \\
\text { shelter }\end{array}$ & Middle - Late Stone Age & 4 & $\begin{array}{l}\text { Biancavilla tephra }(16965-17670 \mathrm{BP}) \\
\text { Campanian Ignimbrite }(39135-39225 \mathrm{BP}) \\
\text { TM-20-2a }(66,560-70,680 \mathrm{BP})\end{array}$ & $\begin{array}{l}\text { Etna, Italy } \\
\text { Campi Flegrei, Italy } \\
\text { Unknown } \\
\text { (Campi Flegrei?) }\end{array}$ & $\begin{array}{l}\text { Douka et al., in press, } \\
\text { Lowe et al., 2012; } \\
\text { Albert et al., in press }\end{array}$ \\
\hline Billa Surgam & India & Cave & Middle Palaeolithic & 1 & Youngest Toba Tuff $(74,100-75,900 \mathrm{BP})$ & Mt. Toba, Indonesia & $\begin{array}{l}\text { Lane et al., 2011b } \\
\text { (Mark et al., 2013) }\end{array}$ \\
\hline
\end{tabular}




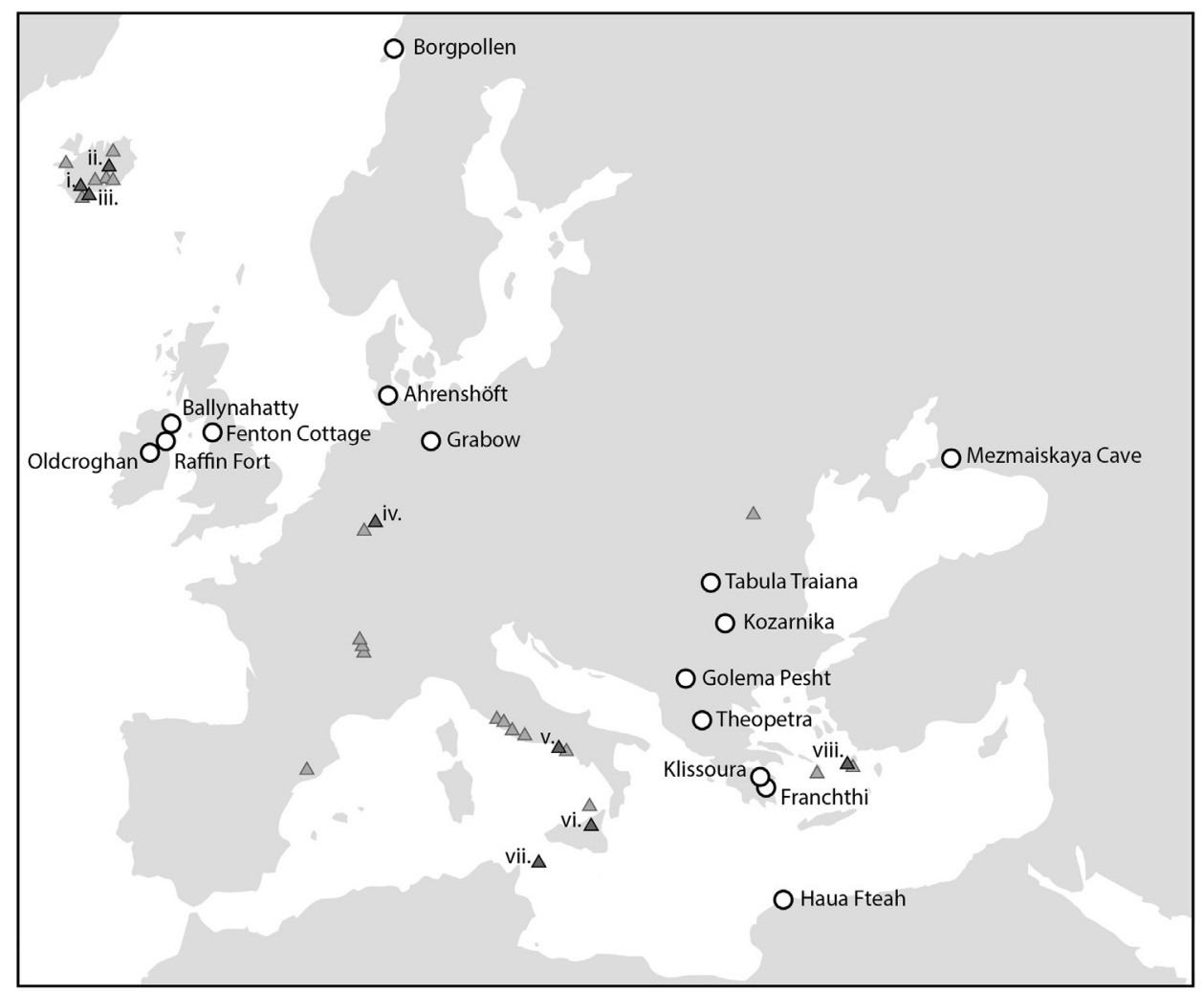

Fig. 1. Map of Europe and the Mediterranean region showing the locations of published archaeological sites containing cryptotephra from Table 1 (open circles), with exception of Billa Surgam, India. Also shown are European volcanic centres, including those referred to in the text: i. Hekla, ii. Askja, iii. Katla, iv. Laacher See, v. Campi Flegrei Volcanic Zone, vi. Mt. Etna, vii. Pantelleria, viii. Nisyros.

varves: Brauer et al., 1999; radiocarbon dating: Vandergoes et al., 2013; optical stimulated luminescence dating: Demuro et al., 2008; historical accounts: Pilcher et al., 1995). Ages of tephra are typically constrained close to the volcanic source, where the eruption stratigraphy is clear and there are samples required for some dating methods (e.g., crystals for ${ }^{40} \mathrm{Ar} /{ }^{39} \mathrm{Ar}$ ). However, the ages of tephra layers can often be further constrained in medialdistal sedimentary archives that have precise age models (e.g., Smith et al., 2013; Staff et al., 2013). These absolute ages can be assigned to the tephra provided it has been robustly correlated to the dated tephra deposit using the composition of the glass shards (Section 3.2). The method therefore offers a valuable additional chronological tool to those excavating Palaeolithic records that predate $50 \mathrm{ka} \mathrm{BP}$, at which point radiocarbon dating is no longer effective, as well as in sites where little organic matter is preserved (e.g. Billa Surgam Cave; Lane et al., 2011b). The profile of cryptotephrochronology research in Palaeolithic archaeology has been raised significantly by work carried out in Europe and North Africa in association with the UK Natural Environment Research Council consortium project "The RESponse of humans to abrupt Environmental Transitions" ( RESET $\left.^{1}\right)$. Notable success has been found in the investigation of sediment records within cave and rock shelter sites (e.g. Boric et al., 2012; Douka et al., 2013; Lowe et al., 2012), in particular where allocthonous sedimentation prevails over the clastic cave sediment component, where erosion and bioturbation are minimised, and where cave openings are reasonably large.

\subsection{Tracing tephra isochrons into archaeological sites}

In many cases archaeological sites have been investigated with the hope of finding cryptotephra from a specific and well-dated volcanic event, for example, the 74 ka Younger Toba Tuff (Lane et al., 2011b) and the 39 ka Campanian Ignimbrite (Boric et al., 2012; Lowe et al., 2012).

The work of Lowe et al. (2012) in a suite of Palaeolithic records across Southern Europe and North Africa: Klissoura in Greece, Kozarnika in Bulgaria, Tabula Traiana in Serbia, Golema Pesht in Macedonia, and Haua Fteah in Libya (Fig. 1), specifically targeted sediments spanning the time period of the Middle to Upper Palaeolithic transition in search of tephra from the Campanian Ignimbrite (CI). The CI super-eruption, dated to $39.3 \pm 0.1 \mathrm{ka} \mathrm{BP}(\mathrm{De}$ Vivo et al., 2001), originated from the Campi Flegrei Volcanic Zone in Southern Italy and dispersed tephra over an area of more than 3 million $\mathrm{km}^{2}$ (Costa et al., 2012; Fedele et al., 2008). Each of the investigated European records lay within the area where the fallout of the $\mathrm{CI}$ has previously been mapped from visible deposits (Fedele et al., 2008), however no visible tephra layers had been identified within the sediments during excavation.

Whist tracing key tephra isochrons may provide valuable regional stratigraphic correlations, the value of cryptotephra layers in providing independent age estimates for a sequence has been less well explored. Long archaeological sequences, within reach of tephra fallout, are likely to preserve more than one cryptotephra layer within their stratigraphy.

The example of the Haua Fteah (Douka et al., 2013) highlights the potential of using tephrochronology as a standard chronological tool, alongside more traditional archaeological dating methods. Within the $14 \mathrm{~m}$ sequence investigated in the Haua Fteah three 
cryptotephra layers, each constrained to an interval of no more than $10 \mathrm{~cm}$ depth, and one previously unrecognised visible tephra layer were found (Douka et al., 2013). The correlation of three of the tephra layers in the Haua Fteah to well-dated Italian tephra horizons (Table 1), provides valuable high-precision age estimates for this important archaeological record.

Tephrochronological constraints may also be of particular use in sites lacking material datable by other techniques, or where conflicting age-models require additional chronological constraints. The discovery of three cryptotephra layers in Theopetra Cave, northwest Greece (Table 1), corroborated the thermoluminescence-based chronology for the site, which was occupied as early as marine isotope stage 6 (Karkanas et al., 2013).

However, in other regions where specific tephra layers are commonly found in palaeoenvironmental archives, there has been less success at locating them within archaeological contexts due to site taphonomy being unsuitable for the preservation of fine layers of ash. Tephra is often described as "blanketing" a landscape, therefore at first consideration open air sites may seem ideal for tephra investigations. However, open air sites are by their very nature exposed, and surface deposits not rapidly buried are easily remobilised and eroded. Even where cryptotephra are found in these kinds of sites, the complex and often shallow stratigraphies may prevent the in-situ preservation of very small tephra concentrations.

Despite lying close to the previously mapped northeast fallout lobe of the 12.9 ka Laacher See Tephra (Fig. 1) from the German Eifel region (Riede et al., 2011), cryptotephra investigations at two Lateglacial, Federmesser-Gruppen, sites in Germany: Ahrenshöft (Housley et al., 2012) and Grabow (Tolksdorf et al., 2013), recovered no ash from the Laacher See eruption. The reported thicknesses in nearby lake basins are likely enhanced by the LST eroded from such exposed ground surfaces. Small amounts of Icelandic cryptotephra were discovered higher in the stratigraphies of both Ahrenshöft and Grabow, but these were distributed within bioturbated near-to surface sediments (Housley et al., 2012; Tolksdorf et al., 2013), which prevented their use as isochron layers.

\subsection{Versatile stratigraphic tie lines}

Beyond providing high precision age-estimates, perhaps the greatest value of tephra layers is that they facilitate correlation at a single moment in time, with no chronological uncertainty. Such correlations may be within the stratigraphy of a single-site, or between geographically widespread archaeological and palaeoenvironmental archives.

The discovery of the $39 \mathrm{ka} \mathrm{Cl}$ as a cryptotephra layer within six Eastern Mediterranean Palaeolithic cave records (Lowe et al., 2012), for example, allows insight into the behaviour of anatomically modern humans at a single point in time, from coastal North Africa, peninsular Greece, Italy and into the Balkans (Fig. 1). The authors extend this archaeological application by using the $\mathrm{CI}$ to further correlate to two palaeoenvironmental archives, the Tenaghi Philipon record in northern Greece and marine core LC-21 in the Aegean. These correlations allow the archaeological data from each site to be set in the context of Mediterranean cooling and increased aridity during the Heinrich 4 event (Lowe et al., 2012). The CI, which has widely been implicated in driving this climatic downturn that may in turn have influenced the demise of the Neanderthals and initial appearance and dispersal of modern humans across Europe (Fedele et al., 2008; Golovanova et al., 2010), is shown to have occurred after the onset of stadial conditions precluding a causal relationship (Lowe et al., 2012). These findings are in support of recently published dates of $>40 \mathrm{ka}$ BP for some of the earliest modern humans from Italy and the UK (Benazzi et al., 2011; Higham et al., 2011).

As the $\mathrm{CI}$ example illustrates, direct correlation between archaeological and regional palaeoenvironmental records provides a means to evaluate hypotheses of environment or climate forcing of past human activity. Whilst a chronological correlation cannot conclusively prove causation, establishing the precise order of events is essential in assessing the possibility of cause and effect.

\section{Methodological approaches}

The detection and characterisation of non-visible tephra layers in sedimentary sequences relies ultimately upon the physical extraction of the tephra glass shards from the host material (following Blockley et al., 2005 Turney, 1998;). This process is usually carried out within the laboratory, after systematic collection of sediment samples from the field.

As with cryptotephra investigations of palaeoenvironmental sequences, understanding the formation and taphonomy of a site is critical, as this knowledge impacts upon sampling strategies, as well as informing the interpretation of glass shard distributions and anomalous chemical signatures. Thus it is imperative to work alongside the experts at the site and during all stages of data collection and interpretation. From a methodological stand point, archaeological sites may be approached in much the same way as palaeoenvironmental sequences, however particular restrictions may apply at the sampling or data interpretation stages. Here we outline the main methodological considerations for cryptotephra investigation of an archaeological sequence, with particular reference to sites within caves and rock shelters.

\subsection{Sampling}

One of the most critical factors in sampling for cryptotephra is the collection of continuous sediment samples spanning the entire sequence of interest. This prevents missing any very low concentration layers of glass shards, composed of grains which are commonly $<100 \mu \mathrm{m}$ in diameter. When sampling from sediment cores or monoliths, as is usually the case in palaeoenvironmental studies, this process is relatively straight forward and typically proceeds in two stages (Fig. 2): first at low resolution, in contiguous $\sim 10 \mathrm{~cm}$ depth samples; then where tephra is located in the laboratory, the sediment is retargeted at $\sim 1 \mathrm{~cm}$ resolution to pin-point the tephra layer more precisely and to explore its distribution.

Within many archaeological excavations however, sampling is performed from the exposed section via a continuous sampling column. In these cases, whilst working from the base of the section upwards to prevent sediment mixing and possible contamination down the face of the profile, samples are best collected in small bags from contiguous $1-2 \mathrm{~cm}$ intervals and the sediment within them homogenised. Smaller sub-samples of these bags can then be amalgamated in the laboratory, to produce low resolution $(10-20 \mathrm{~cm})$ samples for initial cryptotephra investigations (Fig. 2). Rarely can a single sample column record the full stratigraphy of an archaeological site, therefore shorter overlapping columns can be taken, with care to ensure the whole stratigraphy is represented.

Caves and rock shelters may contain a high proportion of coarse clastic material from weathering of the surrounding rock (White, 2007) (Fig. 2) and this may prevent sampling of a site's complete stratigraphy, or demand that lower resolution $(5-10 \mathrm{~cm})$ samples are taken in some areas. Sedimentation rates and sources may also vary rapidly with changing environmental or geomorphic regimes and real land surfaces are rarely flat. With these complications in 


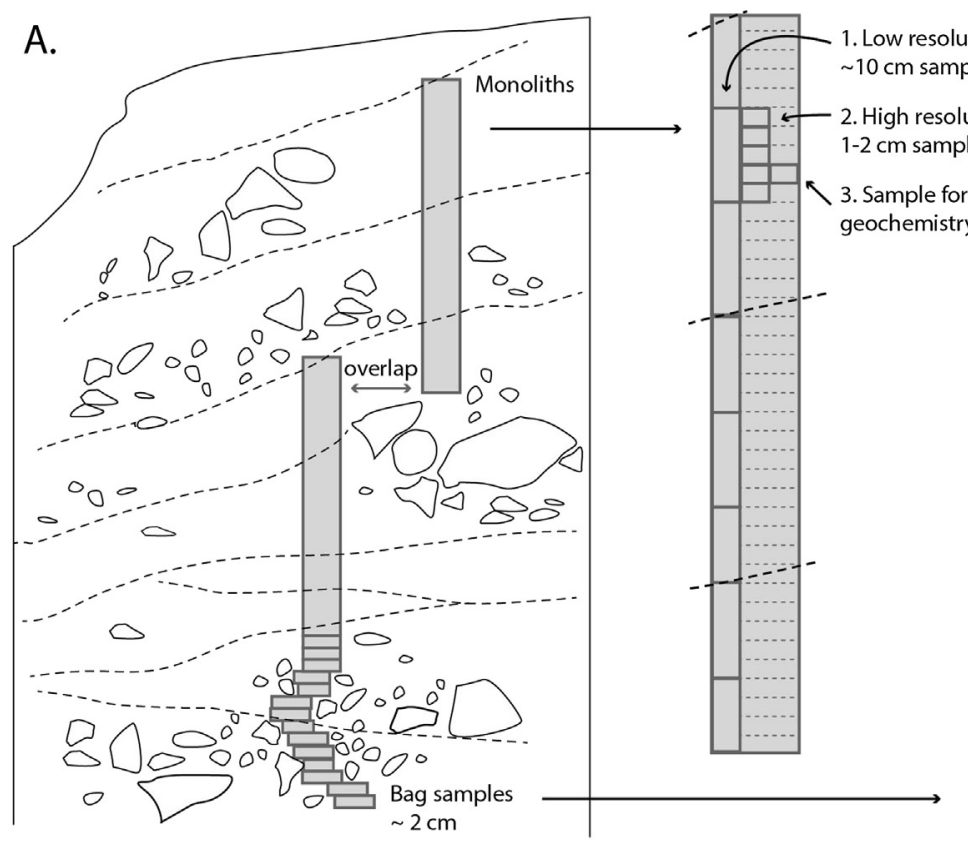

\author{
1. Low resolution: \\ Amalgamated sample from $\sim 5$ bags \\ 2. High resolution: \\ Individual $(2 \mathrm{~cm})$ bag samples
}

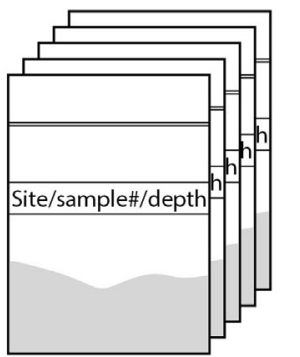

B.

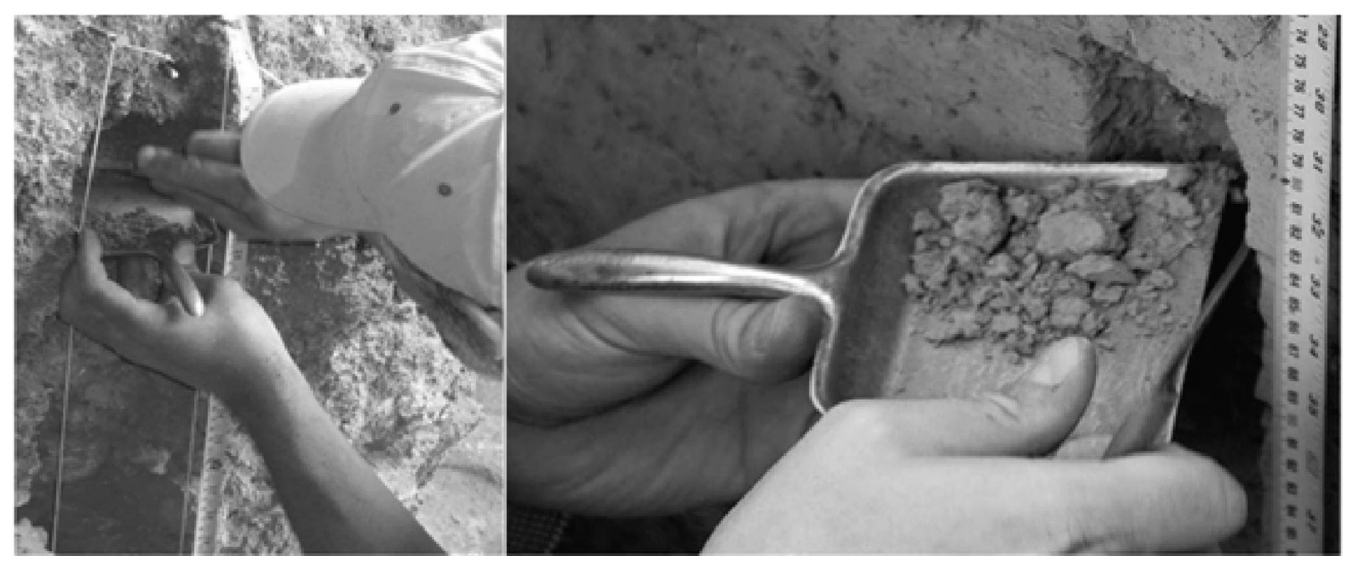

Fig. 2. A. Illustration of sampling approaches within archaeological stratigraphies. Dependent upon the sediment coherence and density of lithic material, either monoliths are cut out of the section face, or $\sim 2 \mathrm{~cm}$ contiguous and continuous samples are taken up a sample column. High resolution "bag sampling" allows lithified or difficult-to-sample areas of the stratigraphy to be worked around, whilst maintaining a continuous sampling approach. To reconstruct low resolution samples, sub-samples of sediment from $\sim 5$ contiguous bags can be amalgamated. Sampling depth intervals should be flexible in order to conform where possible with the archaeological context boundaries. B. Images of samples being collected upward through a sampling column.

mind, samples should be taken with reference to both sedimentological and archaeological section descriptions and the site datum, to ensure that the results can be securely related to the right context, to other proxy techniques, and to aid correct interpretation of any expanded glass shard distributions (Section 3.3).

Cryptotephra investigations are often carried out retrospectively, using sediment samples collected in the field for some other purpose. In such cases, continuous samples may not be available and gaps in the sampled stratigraphy may exist. Whilst this situation is not ideal, within archaeological sites it is rare for tephra glass shards to be distributed over much less than a $10 \mathrm{~cm}$ interval (Fig. 3), therefore it is likely that traces of tephra may still be detected. For example, the $74 \mathrm{ka}$ BP Younger Toba Tuff was found as a cryptotephra within spot samples taken at $10 \mathrm{~cm}$ intervals from the Billa Surgam Cave, India (Lane et al., 2011b). Whilst the exact position of the event horizon could not be precisely pin-pointed, it was confined to a $20 \mathrm{~cm}$ depth interval, which still provides a valuable chronological marker horizon in an otherwise undated sediment sequence.

\subsection{Finding cryptotephra}

Laboratory investigation of the sampled sediment involves the concentration of glass shards using a stepped floatation technique, which extracts sediment fractions of a specified density using a heavy liquid (Blockley et al., 2005; Turney, 1998). Samples are dried, weighed, and if necessary ashed to remove organic material and treated with $1 \mathrm{M} \mathrm{HCl}$ to removed carbonates. Following this the samples are density extracted to concentrate volcanic glass into samples of the correct size and density ranges (commonly 25$80 \mu \mathrm{m}$ and $1.95-2.55 \mathrm{~g} / \mathrm{cm}^{3}$ ). The extracted residue is then mounted for inspection under a high powered optical microscope. Glass shards are counted and then the concentration expressed as shards per gram (s/g) of dried sediment. This method, described by Blockley et al. (2005), can be adapted for use with different sediment types and varied sampling approaches and is therefore a useful guide when designing a methodology for cryptotephra extraction from any sequence. Other approaches used to concentrate tephra glass shards include chemical treatment to remove 


\section{A) Klissoura Column 1}

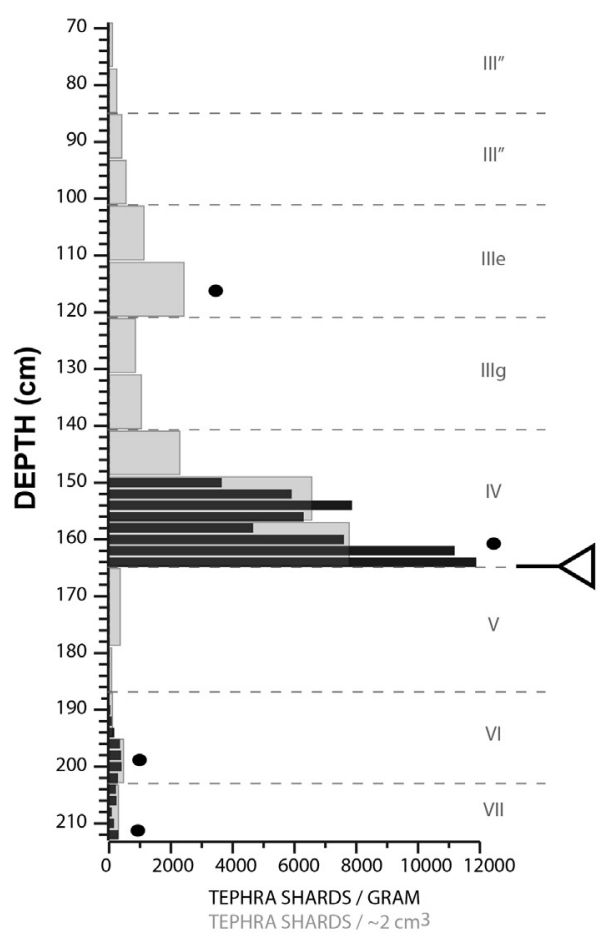

B) Haua Fteah Column A Middle trench (upper)

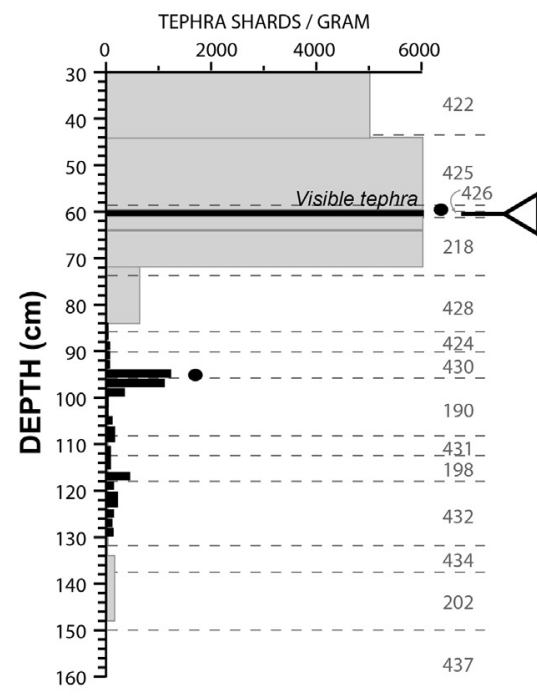

C) Haua Fteah Column A Middle trench (lower)
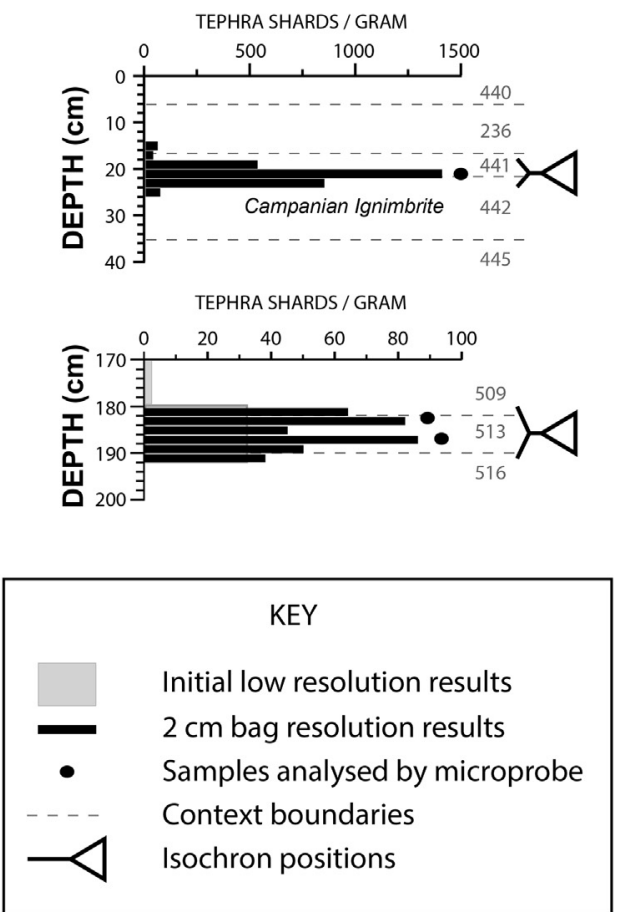

Fig. 3. Plots of tephra glass shard distribution against depth with the designated isochron positions. A) Klissoura Cave, Greece (adapted from Lowe et al., 2012) showing a very sharp boundary at the base of the Campanian Ignimbrite (CI) cryptotephra layer (164 cm), interpreted as rapid input of tephra immediately following air-fall deposition in the site and surrounding slopes. Due to the very dry and loosely consolidated sediments in Klissoura Cave, and the repeated building of and tending to hearths, ash from the $\mathrm{Cl}$ is reworked into $\sim 80 \mathrm{~cm}$ of sediments laid down after the initial input event (verified by compositional and morphological checks). A smaller tephra layer is observed between 194 and $210 \mathrm{~cm}$, separated from the CI by $\sim 14 \mathrm{~cm}$ of ash-free sediment, and is compositionally distinct. B-C) Three examples from the Haua Fteah, Libya (adapted from Douka et al., 2013). B) A cryptotephra distribution profile around the visible Biancavilla tephra at 60-62 cm depth. The host sediment is dry, hard-packed and contains abundant lithic clasts. There is clear evidence of reworking of the ash mostly above, but also up to $90 \mathrm{~cm}$ below the tephra layer (verified by compositional and morphological checks). Upward reworking likely occurs during sediment deposition, whilst downward mobilisation may be due to sediment disturbance during excavation and exposure over the last few decades as well as bioturbation and burrowing. The isochron is placed at the position of the visible ash layer. C) Two smaller cryptotephra layers from the Haua Fteah show lower shard counts and better definition against the surrounding sediments. Layers are confined to $<12 \mathrm{~cm}$ depth. Imported age estimates are applied at context resolution, incorporating the depth uncertainty on the isochron position.

organic material (Dugmore et al., 1992; Rose et al., 1996), however, these methods have been shown to be destructive to glass shards and can reduce the integrity and concentration of tephra recovered (Blockley et al., 2005).

Amendments to the method to consider when processing archaeological samples include:

i. Removal of very coarse material (commonly gravel, lithic debitage, small bones, shells) prior to weighing and processing the sample. This will make sieving easier and also improve the comparability of glass shard concentrations between samples.

ii. Adjusting the sieve mesh size dependent upon the host sediment characteristics and the expected size range of glass shards. Working with fine grained sediments, such as those found in lacustrine silts or residues from ashed peat samples, may negate the need for two sieve mesh sizes, reducing sample preparation time by retaining all material above the finest sieve mesh size (typically $25 \mu \mathrm{m}$ ). Close to a volcanic source coarser glass shard sizes may be expected, therefore the standard $80 \mu \mathrm{m}$ mesh size may be inappropriate and a larger mesh size may be used to maximise glass shard recovery.

iii. Due to the high clay content of some cave deposits (White, 2007), sieving may be slow as it takes a while for the sediment to break down. It may be useful to re-sieve the extracted residue through the lowest sieve mesh size following the density separation. This will ensure all clay material is removed and microscope slides are clean enough for examination.

iv. Clay material can get trapped within vesicles in glass shards, which may cause some birefringence under cross-polarised light. Therefore, careful optical examination is essential.

\subsection{Interpreting glass shard concentrations}

After glass shard concentrations have been fully quantified it is usual to plot them up against the site's stratigraphy to evaluate the positions and stratigraphic integrity of the cryptotephra layers as event horizons (Fig. 3). Cryptotephra layers affected by reworking, bioturbation or sediment erosion may be characterised by shard concentrations distributed over extended depths (Fig. 3). Other proxies may also be disturbed and this may assist in detecting these processes.

Complex depositional regimes caused difficulties with the interpretation of the tephrostratigraphy of the Haua Fteah, Libya (Section 2.1). The upper metre of investigated sediments shows evidence of high sedimentation rates, occurring with increased breccia content and many punctuated high-energy in-wash events (Douka et al., 2013). The $2 \mathrm{~cm}$ thick Biancavilla tephra was found 
reworked over more than $70 \mathrm{~cm}$ depth, mostly above the visible horizon which prevented detection of any low concentration cryptotephra layers within the uppermost sample column (Fig. 3). The cryptotephra layers in the site however, found in an offset lower sample column, were clearly resolved to within $10 \mathrm{~cm}$ depth and whilst this is not as refined as one might expect from a peat or lake sediment core, it is appropriate to the resolution of the archaeological and sedimentological investigations within the cave (Fig. 3).

Where glass shards show a sudden appearance in the stratigraphy, then concentrations decrease gradually upwards, the basal rise is usually interpreted as marking the stratigraphic position of the tephra event and the tail as tephra reworked within the site and/or continuing to be washed off the landscape (Fig. 3). Small concentrations of tephra may also be present in the stratigraphy below the peak shard concentration, which may represent in-situ downward mobilisation of tephra shards, e.g. by processes such as compaction, bioturbation or water percolation (e.g. Payne and Gehrels, 2010). Where the exact position of an event stratigraphic layer cannot be defined, depth uncertainty should be built into dates imported into site age models.

\subsection{Chemical characterisation}

The chemical composition of the glass shards is the most unique characteristic of the tephra and therefore determining the glass composition is crucial for correlating the tephra and using the layer as a chronostratigraphic marker. Archaeological cryptotephra investigations require the generation of compositional data from small concentrations of tephra that are typically composed of very small shards $(<80 \mu \mathrm{m})$ with irregular morphologies. Furthermore, the typically high biogenic silica content of archaeological sediment samples make it critical to consider extra steps toward the isolation of small tephra concentrations for compositional analysis. One approach is to manually pick individual tephra shards from the host sediment following the standard density extraction procedure. Fig. 4 illustrates the use of a gas-chromatography syringe, mounted on a micromanipulator, to extract individual tephra shards from their host sediment from samples suspended in distilled water on a welled-slide, on a high powered optical microscope. Whilst not simple to perform, the samples generated contain only tephra shards and therefore increase efficiency by reducing the instrument time required for analyses.

The tephra samples are prepared for compositional analysis by placing the glass shards on a flat epoxy resin mount and covering them with a thin film of epoxy resin (e.g., Struers SpeciFix resin). Once the resin has cured the samples are ground and polished to intersect the shards and expose a flat surface for analysis.

The major and minor oxide compositions of the individual shards, such as $\mathrm{SiO}_{2}, \mathrm{CaO}, \mathrm{FeO}, \mathrm{K}_{2} \mathrm{O}, \mathrm{Na}_{2} \mathrm{O}, \mathrm{Al}_{2} \mathrm{O}_{3}, \mathrm{MgO}, \mathrm{MnO}, \mathrm{TiO}_{2}$, $\mathrm{P}_{2} \mathrm{O}_{5}$, and $\mathrm{Cl}$, are routinely determined using an electron microprobe (EMP). Glass is easily damaged by the electron beam, losing mobile elements like sodium (Miotello and Mazzoldi, 1982), therefore instrument setup and operating conditions must be carefully selected to obtain accurate data (Hunt and Hill, 2001). The analytical protocols that should be used for the chemical characterisation of glass shards using an electron microprobe are outlined in detail in Kuehn et al. (2011), which highlights that low beam currents ( $<10 \mathrm{nA})$ and large spot sizes ( $10 \mu \mathrm{m}$ defocussed beam) are required to obtain accurate data.

In recent years there have been substantial advances in mass spectrometry methods, and small single shards $(>40 \mu \mathrm{m})$ can now be analysed on conventional laser ablation inductively coupled mass spectrometry (LA-ICPMS) instruments (e.g., Pearce et al., 2011; Tomlinson et al., 2010). A full suite of trace elements including rare earth elements can be obtained for each shard, which help validate tephra correlations based on major element compositions. Furthermore, the incompatible trace elements are particularly unique for different eruptions and therefore ideal for correlating tephra (Tomlinson et al., 2012).

It should be noted however, that not all tephra layers can be discriminated based upon their chemical composition, sometimes even when trace element data is collected (Lane et al., 2012). This is most common in subsequent eruptions from a single volcanic source, such as the Lateglacial and Early Holocene silicic eruptions of Katla, Iceland (Housley et al., 2012). In such situations correlations should only be made with caution and if possible, with the support of other robust dating or stratigraphic evidence.

All compositional data from tephra glass shards in archaeological sites needs to be carefully checked to ensure that anthropogenic processes at the site have not compromised the glass compositions, e.g. burning may accelerate alkali exchange. More information on the chemical characterisation of tephra layers and the correlation based on glass chemistry can be found in Lowe (2011).

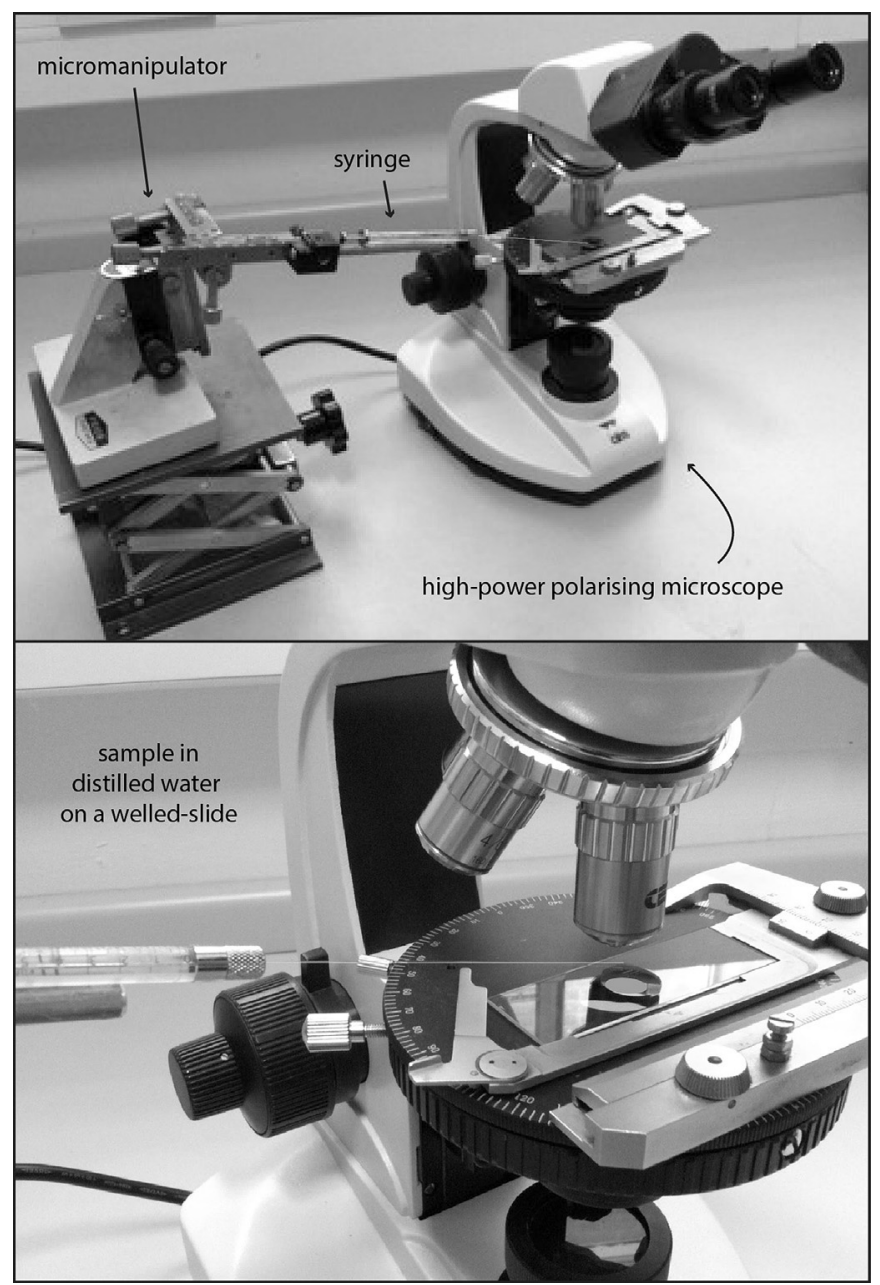

Fig. 4. Images of the set-up for picking shards manually under high powered microscopy, using a gas chromatography syringe, mounted on a micromanipulator. The density-extracted sample is placed in water onto a welled slide and inspected for glass shards. Shards are drawn up by the syringe and then extruded onto a stub or slide, as appropriate, and sealed with epoxy resin before sectioning for microprobe analysis. 


\section{Conclusions}

The value of cryptotephra layers as reliable event horizons within archaeological sequences has now been demonstrated by a breadth of published examples, from Neolithic wetland sites to Palaeolithic cave records. Interestingly, in the case of cave records, most of the successful cryptotephra investigations have been in sites very close to, or well within, mapped visible tephra fallout areas for specific eruptions (e.g., Douka et al., 2013; Lane et al., 2011b; Lowe et al., 2012). In many cases therefore, the tephra layers are cryptic not because of their distance from source, but due to the site's taphonomy. An awareness of the dispersal and deposition of the most widespread tephra layers in any region is therefore of key importance when considering cryptotephra investigations within archaeological archives.

Where site location and taphonomy allow, non-visible tephra isochrons can provide independent age estimates for sites, which are invaluable in establishing robust chronologies based upon multiple dating techniques. Tephra isochrons also facilitate precise inter-site correlations between archaeological and/or palaeoenvironmental records. The adoption of cryptotephrochronology as an integral tool in archaeological excavation can only further the network of archives within which high-precision correlations can be made. The potential to find widespread cryptotephra layers and even to make cross-continental correlations highlights the opportunity to compare records with increased temporal precision, allowing more robust assessment of cause and effect in human prehistory.

\section{Acknowledgements}

This review is a contribution to the UK Natural Environment Research Council RESET Consortium Grant (NE/E015670/1 and NE/ E01531X/1). This is RHOXTOR paper number RHOX/033. C.S.L. is funded by a fellowship from The Leverhulme Trust.

\section{References}

Abbott, P.M., Davies, S.M., 2012. Volcanism and the Greenland ice-cores: the tephra record. Earth-Sci. Rev. 115, 173-191.

Albert, P.G., Tomlinson, E.L., Lane, C.S., Wulf, S., Smith, V., Coltelli, M., Keller, J., Lo Castro, D., Manning, C.J., Müller, W., Menzies, M.A., 2013. Late glacial explosive activity on Mount Etna: implications for proximal-distal tephra correlations and the synchronisation of Mediterranean archives. J. Volcanol. Geotherm. Res. 256, $9-26$.

Balascio, N.L., Wickler, S., Narmo, L.E., Bradley, R.S., 2011. Distal cryptotephra found in a Viking boathouse: the potential for tephrochronology in reconstructing the Iron Age in Norway. J. Archaeol. Sci. 38, 934-941.

Benazzi, S., Douka, K., Fornai, C., Bauer, C.C., Kullmer, O., Svoboda, J., Pap, I., Mallegni, F., Bayle, P., Coquerelle, M., Condemi, S., Ronchitelli, A., Harvati, K., Weber, G.W., 2011. Early dispersal of modern humans in Europe and implications for Neanderthal behaviour. Nature 479, 525-528.

Blockley, S.P.E., Pyne-O'Donnell, S.D.F., Lowe, J.J., Matthews, I.P., Stone, A., Pollard, A.M., Turney, C.S.M., Molyneux, E.G., 2005. A new and less destructive laboratory procedure for the physical separation of distal glass tephra shards from sediments. Quat. Sci. Rev. 24, 1952-1960.

Blockley, S.P.E., Blockley, S.M., Donahue, R.E., Lane, C.S., Lowe, J.J., Pollard, A.M., 2006. The chronology of abrupt climate change and Late Upper Palaeolithic human adaptation in Europe. J. Quat. Sci. 21, 575-584.

Blockley, S.P.E., Lane, C.S., Lotter, A.F., Pollard, A.M., 2007. Evidence for the presence of the Vedde Ash in Central Europe. Quat. Sci. Rev. 26, 3030-3036.

Blockley, S.P.E., Lane, C.S., Hardiman, M., Rasmussen, S.O., Seierstad, I.K., Steffensen, J.P., Svensson, A., Lotter, A.F., Turney, C.S.M., Bronk Ramsey, C., 2012. Synchronisation of palaeoenvironmental records over the last 60,000 years, and an extended INTIMATE 1 event stratigraphy to 48,000 b2k. Quat. Sci. Rev. 36, 2-10.

Boric, D., Dimitrijevic, V., White, D., Lane, C.S., French, C., Cristiani, E., 2012. Early modern human settling of the 'Danube corridor': the Middle to Upper Palaeolithic site of Tabula Traiana Cave in the Danube Gorges (Serbia). Antiquity 86, 334 (Antiquity Project Gallery).

Brauer, A., Endres, C., Negendank, J.F.W., 1999. Lateglacial calendar year chronology based on annually laminated sediments from Lake Meerfelder Maar, Germany. Quat. Int. 61, 17-25.
Chambers, F.M., Daniell, J.R.G., Hunt, J.B., Molloy, K., O’Connell, M., 2004. Tephrostratigraphy of an Loch Mór, Inis Oírr, western Ireland: implications for Holocene tephrochronology in the northeastern Atlantic region. Holocene 14, 703-720.

Costa, A., Folch, A., Macedonio, G., Giaccio, B., Isaia, R., Smith, V.C., 2012. Transport and impact of volcanic ash from the Campanian Ignimbrite super-eruption. Geophys. Res. Lett. 39, L10310. http://dx.doi.org/10.1029/2012GL051605.

Davies, S.M., Branch, N.P., Lowe, J.J., Turney, C.S.M., 2002. Towards a European tephrochronological framework for Termination 1 and the Early Holocene. Philos. Trans. Math. Phys. Eng. Sci. (Ser. A) 360, 767-802.

Davies, S.M., Elmquist, M., Bergman, J., Wohlfarth, B., Hammarlund, D., 2007. Cryptotephra sedimentation processes within two lacustrine sequences from west central Sweden. Holocene 17, 319-330.

Davies, S.M., Abbott, P.M., Pearce, N.J.G., Wastegård, S., Blockley, S.P.E., 2012. Integrating the INTIMATE records using tephrochronology: rising to the challenge. Quat. Sci. Rev. 36, 11-27.

De Vivo, B., Rolandi, G., Gans, P.B., Calvert, A., Bohrson, W.A., Spera, F.J., Belkin, H.E., 2001. New constraints on the pyroclastic eruptive history of the Campanian volcanic Plain (Italy). Mineral. Petrol. 73, 47-65.

Demuro, M., Roberts, R.G., Froese, D.G., Arnold, L.J., Brock, F., Ramsey, C.B., 2008. Optically stimulated luminescence dating of single and multiple grains of quartz from perennially frozen loess in western Yukon Territory, Canada: comparison with radiocarbon chronologies for the late Pleistocene Dawson tephra. Quat. Geochronol. 3, 346-364.

Douka, K., Jacobs, Z., Lane, C., Grün, R., Farr, L., Hunt, C., Inglis, R., Reynolds, T., Albert, P., Aubert, M., Barker, G.W.W. , 2013. The chronostratigraphy of the Haua Fteah cave (Cyrenaica, northeast Libya). J. Human Evol. (in press). http:// dx.doi.org/10.1016/j.jhevol.2013.10.001.

Dugmore, A.J., 1989a. Tephrochronology and UK archaeology. In: Budd, P., Chapman, C., Jackson, C., Janaway, R., Ottoway, B. (Eds.), The Proceedings of Archaeological Sciences 1989. Oxbow Books, Oxford, pp. 242-250.

Dugmore, A.J., 1989b. Icelandic volcanic ash in Scotland. Scott. Geogr. Mag. 105, $168-172$.

Dugmore, A.J., Newton, A.J., Sugden, D.E., Larsen, G., 1992. Geochemical stability of fine-grained silicic Holocene tephra in Iceland and Scotland. J. Quat. Sci. 7, $173-183$.

Fedele, F.G., Giaccio, B., Hajdas, I., 2008. Timescales and cultural process at 40,000 $\mathrm{BP}$ in the light of the Campanian Ignimbrite eruption, Western Eurasia. J. Hum. Evol. 55, 834-857.

Finsinger, W., Lane, C.S., van Den Brand, G.J., Wagner-Cremer, F., Blockley, S.P.E., Lotter, A.F., 2011. The lateglacial Quercus expansion in the southern European Alps: rapid vegetation response to a late Allerød climate warming? J. Quat. Sci. 26, 694-702.

Golovanova, L.V., Doronichev, V.B., Cleghorn, N.E., Koulkova, M.A., Sapelko, T.V., Shackley, M.S., 2010. Significance of ecological factors in the middle to upper paleolithic transition. Curr. Anthropol. 51, 655-691.

Higham, T., Compton, T., Stringer, C., Jacobi, R., Shapiro, B., Trinkaus, E., Chandler, B., Gröning, F., Collins, C., Hillson, S., O'Higgins, P., FitzGerald, C., Fagan, M., 2011. The earliest evidence for anatomically modern humans in northwestern Europe. Nature 479, 521-524.

Housley, R.A., Blockley, S.P.E., Matthews, I.P., MacLeod, A., Lowe, J.J., Ramsay, S., Miller, J.J., Campbell, E.N., 2010. Late Holocene vegetation and palaeoenvironmental history of the Dunadd area, Argyll, Scotland: chronology of events. J. Archaeol. Sci. 37, 577-593.

Housley, R.A., Lane, C.S., Cullen, V.L., Weber, M.-J., Riede, F., Gamble, C.S., Brock, F., 2012. Icelandic volcanic ash from the Late-glacial open-air archaeological site of Ahrenshöft LA 58 D, North Germany. J. Archaeol. Sci. 39, 708-716.

Hunt, J.B., Hill, P.G., 2001. Tephrological implications of beam size - sample-size effects in electron microprobe analysis of glass shards. J. Quat. Sci. 16, 105117.

Jensen, B.J., Pyne-O’Donnell, S., Plunkett, G., Froese, D.G., Hughes, P., Pilcher, J.R., Hall, V.A., 2012. Intercontinental distribution of an Alaskan volcanic ash. In: American Geophysical Union Fall Meeting, 3-7th December 2012. Session V43B: Quaternary Tephrochronology: Advances and Applications II Posters. Abstract: V43B-2832.

Karkanas, P., White, D., Lane, C.S., Cullen, V.L, Stringer, C., Davies, S.W.G., Smith, V.C, Ntinou, M., Tsartsidou, G., Kyparissi-Apostolika, N., 2013. Tephra chronostratigraphy and climatic events between the MIS6/5 transition and the beginning of MIS3 in Theopetra Cave. central Greece. Quat. Sci. Rev (submitted for publication).

Kuehn, S.C., Froese, D.G., Shane, P.A.R., INTAV Intercomparison Participants, 2011. The INTAV intercomparison of electron-beam microanalysis of glass by tephrochronology laboratories: results and recommendations. Quat. Int 246, 19-47.

Lane, C.S., Blockley, S.P.E., Bronk Ramsey, C., Lotter, A.F., 2011a. Tephrochronology and absolute centennial scale synchronisation of European and Greenland records for the last glacial to interglacial transition: a case study of Soppensee and NGRIP. Quat. Int. 246, 145-156.

Lane, C., Haslam, M., Petraglia, M., Ditchfield, P., Smith, V., Korisettar, R., 2011b. Cryptotephra from the 74 ka BP Toba super-eruption in the Billa Surgam caves, southern India. Quat. Sci. Rev. 30, 1819-1824.

Lane, C.S., Blockley, S.P.E., Mangerud, J., Smith, V.C., Lohne, Ø.S., Tomlinson, E.L., Matthews, I.P., Lotter, A.F., 2012. Was the 12.1 ka Icelandic Vedde Ash one of a kind? Quat. Sci. Rev. 33, 87-99.

Lane, C.S., Chorn, B.T., Johnson, T.C., 2013. Ash from the Toba supereruption in Lake Malawi shows no volcanic winter in East Africa at 75 ka. Proc. Natl. Acad. Sci. U. S. A. $110,8025-8029$. 
Lawson, I.T., Swindles, G.T., Plunkett, G., Greenberg, D., 2012. The spatial distribution of Holocene cryptotephras in north-west Europe since $7 \mathrm{ka}$ : implications for understanding ash fall events from Icelandic eruptions. Quat. Sci. Rev. 41, 57-66.

Lowe, D.J., 2011. Tephrochronology and its application: a review. Quat. Geochronol. 6, 107-153.

Lowe, J., Barton, N., Blockley, S., Ramsey, C.B., Cullen, V.L., Davies, W., Gamble, C. Grant, K., Hardiman, M., Housley, R., Lane, C.S., Lee, S., Lewis, M., MacLeod, A., Menzies, M., Müller, W., Pollard, M., Price, C., Roberts, A.P., Rohling, E.J., Satow, C., Smith, V.C., Stringer, C.B., Tomlinson, E.L., White, D., Albert, P., Arienzo, I., Barker, G., Borić, D., Carandente, A., Civetta, L., Ferrier, C., Guadelli, J.L., Karkanas, P., Koumouzelis, M., Müller, U.C., Orsi, G., Pross, J., Rosi, M., Shalamanov-Korobar, L., Sirakov, N., Tzedakis, P.C., 2012. Volcanic ash layers illuminate the resilience of Neanderthals and early modern humans to natural hazards. Proc. Natl. Acad. Sci. U. S. A. 109, 13532-13537.

Mangerud, J., Lie, S.E., Furnes, H., Kristiansen, I.L., Lømo, L., 1984. A Younger Dryas ash bed in western Norway, and its possible correlations with tephra in cores from the Norwegian Sea and the North Atlantic. Quat. Res. 21, 85-104.

Mark, D.F., Petraglia, M., Smith, V.C., Morgan, L.E., Barfod, D.N., Ellis, B.S., Pearce, N.J. Pal, J.N., Korisettar, R., 2013. A high-precision ${ }^{40} \mathrm{Ar} /{ }^{39} \mathrm{Ar}$ age for the Young Toba Tuff and dating of ultra-distal tephra: forcing of Quaternary climate and implications for hominin occupation of India. Quat. Geochronol. (in press) http:// dx.doi.org/10.1016/j.quageo.2012.12.004.

Miotello, A., Mazzoldi, P., 1982. Numerical analysis of field-assisted sodium migration in electron-irradiated glasses. J. Phys. C Solid State Phys. 15, 5615-5621.

Morgan, L.E., Renne, P.R., Kieffer, G., Piperno, M., Gallotti, R., Raynal, J.-, 2012 A chronological framework for a long and persistent archaeological record: Melka Kunture, Ethiopia. J. Hum. Evol. 62, 104-115.

Newman, C., O'Connell, M., Dillon, M., Molloy, K., 2007. Interpretation of charcoa and pollen data relating to a late Iron Age ritual site in eastern Ireland: a holistic approach. Veg. Hist. Archaeobotany 16, 349-365.

Payne, R., Gehrels, M., 2010. The formation of tephra layers in peatlands: an experimental approach. Catena 81, 12-23.

Payne, R.J., Kilfeather, A.A., van der Meer, J.J.M., Blackford, J.J., 2005. Experiments on the taphonomy of tephra in peat. Suo 56, 147-156.

Pearce, N.J.G. Perkins, W.T. Westgate, J.A., Wade, S.C. 2011. Trace-element microanalysis by LA-ICP-MS: the quest for comprehensive chemical characterisation of single, sub-10 $\mu \mathrm{m}$ volcanic glass shards. Quat. Int. 246, 57-81.

Pilcher, J.R., Hall, V.A., McCormac, F.G., 1995. Dates of Holocene Icelandic volcanic eruptions from tephra layers in Irish peats. Holocene 5, 103-110.

Plunkett, G.M., Pilcher, J.R., Gerry McCormac, F., Hall, V.A., 2004. New dates for first millennium BC tephra isochrones in Ireland. Holocene 14, 780-786.

Plunkett, G., Carroll, F., Hartwell, B., Whitehouse, N.J., Reimer, P.J., 2008. Vegetation history at the multi-period prehistoric complex at Ballynahatty, Co. Down, Northern Ireland. J. Archaeol. Sci. 35, 181-190.

Plunkett, G., Whitehouse, N.J., Hall, V.A., Charman, D.J., Blaauw, M., Kelly, E. Mulhall, I., 2009. A multi-proxy palaeoenvironmental investigation of the findspot of an Iron Age bog body from Oldcroghan, Co. Offaly, Ireland. J. Archaeol. Sci. 36, 265-277.

Pyle, D.M., Ricketts, G.D., Margari, V., van Andel, T.H., Sinitsyn, A.A., Praslov, N.D., Lisitsyn, S., 2006. Wide dispersal and deposition of distal tephra during the Pleistocene 'Campanian Ignimbrite/Y5' eruption, Italy. Quat. Sci. Rev. 25 $2713-2728$

Riede, F., Bazely, O., Newton, A.J., Lane, C.S., 2011. A Laacher See-eruption supplement to Tephrabase: investigating distal tephra fallout dynamics. Quat. Int. 246, 134-144.

Rose, N.L., Golding, P.N.E., Battarbee, R.W., 1996. Selective concentration and enumeration of tephra shards from lake sediment cores. Holocene 6, 243-246.

Smith, V.C., Mark, D.F., Staff, R.A., Blockley, S.P.E., Bronk-Ramsey, C., Bryant, C.L. Nakagawa, T., Han, K.K., Weh, A., Takemura, K., Danhara, T., Suigetsu 2006
Members, 2011. Toward establishing precise ${ }^{40} \mathrm{Ar} /{ }^{39} \mathrm{Ar}$ chronologies for Late Pleistocene palaeoclimate archives: an example from the Lake Suigetsu (Japan) sedimentary record. Quat. Sci. Rev. 30, 2845-2850.

Smith, V.C., Staff, R.A., Blockley, S.P.E., Bronk Ramsey, C., Nakagawa, T., Mark, D.F., Takemura, K., Danhara, T., 2013. Identification and correlation of visible tephras in the Lake Suigetsu SG06 sedimentary archive, Japan: chronostratigraphic markers for synchronising of east Asian/west Pacific palaeoclimatic records across the last $150 \mathrm{ka}$. Ouat. Sci. Rev. 61, 121-137.

Staff, R.A., Nakagawa, T., Schlolaut, G., Marshall, M.H., Brauer, A., Lamb, H.F., Bronk Ramsey, C., Bryant, C.L., Brock, F., Kitagawa, H., van der Plicht, J., Payne, R.L. Smith, V.C., Mark, D.F., MacLeod, A., Blockley, S.P.E., Schwenninger, J. Tarasov, P.E., Haraguchi, T., Gotanda, K., Yonenobu, H., Yokoyama, Y., Suigetsu 2006 project members, 2013. The multiple chronological techniques applied to the Lake Suigetsu (SG06) sediment core. Boreas 42, 259-266.

Swindles, G.T., Lawson, I.T., Savov, I.P., Connor, C.B., Plunkett, G., 2011. A 7000 yr perspective on volcanic ash clouds affecting northern Europe. Geology 39, 887-890.

Tamburrino, S., Insinga, D.D., Sprovieri, M., Petrosino, P., Tiepolo, M., 2012. Major and trace element characterization of tephra layers offshore Pantelleria Island: insights into the last $200 \mathrm{ka}$ of volcanic activity and contribution to the Mediterranean tephrochronology. J. Quat. Sci. 27, 129-140.

Tolksdorf, J.F., Turner, F. Kaiser, K., Eckmeier, E, Stahlschmidt, M., Housley, R.A. Breest, K., Veil, S., 2013. Multiproxy analyses of stratigraphy and palaeoenvironment of the Late Palaeolithic Grabow floodplain site, northern Germany. Geoarchaeology 28, 50-65.

Tomlinson, E.L., Thordarson, T., Müller, W., Thirlwall, M., Menzies, M.A. 2010 Microanalysis of tephra by LA-ICP-MS - strategies, advantages and limitations assessed using the Thorsmörk ignimbrite (Southern Iceland). Chem. Geol. 279, 73-89.

Tomlinson, E.L., Arienzo, I., Civetta, L., Wulf, S., Smith, V.C., Hardiman, M., Lane, C.S. Carandente, A., Orsi, G., Rosi, M., Müller, W., Menzies, M.A., 2012. Geochemistry of the Phlegraean fields (Italy) proximal sources for major Mediterranean tephras: implications for the dispersal of Plinian and co-ignimbritic components of explosive eruptions. Geochim. Cosmochim. Acta 93, 102-128.

Turney, C.S.M., 1998. Extraction of rhyolitic component of Vedde microtephra from minerogenic lake sediments. J. Paleolimnol. 19, 199-206.

Vandergoes, M.J., Hogg, A.G., Lowe, D.J., Newnham, R.M., Denton, G.H., Southon, J., Barrell, D.J.A., Wilson, C.J.N., McGlone, M.S., Allan, A.S.R., Almond, P.C. Petchey, F., Dabell, K., Dieffenbacher-Krall, A.C., Blaauw, M., 2013. A revised age for the Kawakawa/Oruanui tephra, a key marker for the Last Glacial Maximum in New Zealand. Quat. Sci. Rev. 74, 195-201.

Wastegard, S., 2002. Early to middle Holocene silicic tephra horizons from the Katla volcanic system, Iceland: new results from the Faroe Islands. J. Quat. Sci. 17 723-730.

Wells, C., Huckerby, E., Hall, V., 1997. Mid- and late-Holocene vegetation history and tephra studies at Fenton Cottage, Lancashire, U.K. Veg. Hist. Archaeobotany 6, 153-166.

White, W.B., 2007. Cave sediments and paleoclimate. J. Cave Karst Stud. 69, 76-93.

WoldeGabriel, G., Hart, W.K. Katoh, S., Beyene, Y., Suwa, G., 2005. Correlation of Plio-Pleistocene Tephra in Ethiopian and Kenyan rift basins: temporal calibration of geological features and hominid fossil records. J. Volcanol. Geotherm. Res. 147, 81-108.

Wulf, S., Kraml, M., Brauer, A., Keller, J., Negendank, J.F.W., 2004. Tephrochronology of the 100ka lacustrine sediment record of Lago Grande di Monticchio (southern Italy). Quat. Int. 122, 7-30.

Wulf, S., Keller, J., Paterne, M., Mingram, J., Lauterbach, S., Opitz, S., Sottili, G. Giaccio, B., Albert, P.G., Satow, C., Tomlinson, E.L., Viccaro, M., Brauer, A., 2012 The 100-133 ka record of Italian explosive volcanism and revised tephrochronology of Lago Grande di Monticchio. Quat. Sci. Rev. 58, 104-123. 